\title{
Genetic Study of Phenylthiocarbamide (PTC) Taste Sensitivity In Population of The Osing in Kemiren Village-Banyuwangi
}

(Studi Genetik Terhadap Kemampuan Mengecap Phenylthiocarbamide (PTC) Pada

\author{
Populasi Suku Osing Desa Kemiren Kabupaten Banyuwangi) \\ Fenny Indriani, Syubbanul Wathon, Rike Oktarianti ${ }^{*}$ \\ Jurusan Biologi, Fakultas Matematika dan Ilmu Pengetahuan Alam, Universitas Jember \\ Jl. Kalimantan 37 Jember 68121 Indonesia
}

\section{ABSTRACT}

The ability to taste phenylthiocarbamide (PTC), is autosomal trait inherited in a simple Mendelian recessive pattern. The frequency of Taster and non-Taster allele is varies in different populations. The purpose of the research is to investigate the prevalence, gene frequency and genotype frequency of taster $(\mathrm{T})$ and non taster (ts of Osing population in Kemiren-Banyuwangi. PTC serial dilution method was used to assess the PTC Taster and non-Taster phenotypes. The Hardy-Weinberg method was used to determine allele frequencies. The total of samples were 227 people, male were 117 and female were 110 with age range of 15-30 years were randomly selected. The result showed that the Osing population as Taster were $210(92,52 \%)$ and non Taster were 17 samples $(7,48 \%)$. The allele frecuency of Taster $(\mathrm{T})$ was 0,73 and non Taster $(\mathrm{t})$ was 0,27 respectively. The genotype frequency of dominant Taster (TT) was 0,54 , heterozygosity Taster $(\mathrm{Tt})$ was 0,39 , and genotype of non Taster (tt) was 0,07 .

Kemampuan mengecap rasa pahit dari Phenylthiocarbamide (PTC) merupakan model inhereditas autosomal resesif hukum Mendel sederhana. Frekuensi alel Taster dan non Taster bervariasi di setiap populasi. Tujuan dari penelitian ini adalah untuk mengetahui prevalensi alel, frekuensi gen, dan frekuensi genotip individu Taster $(\mathrm{T})$ dan non Taster $(\mathrm{t})$ pada populasi Suku Osing Desa Kemiren Kabupaten Banyuwangi. PTC merupakan senyawa yang sering digunakan untuk megetahui fenotip (Taster dan non Taster) suatu individu. Keseimbangan genetik frekuensi alel Taster dan non Taster diuji menggunakan metode Hukum Hardy-Weinberg. Sampel yang diamati pada penelitian ini sebanyak 227 orang dengan 117 orang laki-laki dan 110 orang perempuan berusia 15-30 tahun yang dipilih secara acak. Hasil menunjukkan bahwa 210 (92,52\%) dikategorikan sebagai Taster dan 17 (7,48\%) dikategorikan sebagai non Taster. Frekuensi alel Taster (T) sebesar 0,73 dan non Taster sebesar 0,27. Frekuensi genotip Taster dominan(TT) sebesar 0,54, Taster heterozigot (Tt) sebesar 0,39, dan non Taster (tt) sebesar 0,07.

Keywords: Phenylthiocarbamide (PTC), Taster, non Taster.

*)Corresponding author:

Rike Oktarianti

E-mail: rike.fmipa@unej.ac.id

\section{PENDAHULUAN}

Suku Osing terdapat di desa Kemiren terletak $5 \mathrm{~km}$ dari Kota Banyuwangi dan $3 \mathrm{~km}$ dari pusat kecamatan Glagah. Suku ini memiliki adat istiadat yang kental dan masih terjaga [1]. Salah satu yang unik di desa ini adalah adat pernikahan yang dikenal dengan perkawinan Upek-Upekan. Tradisi ini merupakan sistem perkawinan tertutup antara penduduk Osing desa Kemiren dengan penduduk Osing desa Kemiren lainnya [2]. Model perkawinan ini merupakan sistem perkawinan endogami [3]. Perkawinan endogami dapat meningkatkan homozigositas dan menurunkan heterozigositas [4] atau mengurangi variasi genetik [5].

Salah satu variasi genetik pada populasi manusia adalah kemampuan mengecap rasa pahit dari PTC 
(Phenylthiocarbamide). Kemampuan mengecap PTC ini merupakan salah satu penanda genetik pada manusia[6]. Senyawa PTC dapat dideteksi oleh reseptor pengecap sebagai senyawa yang memiliki rasa hambar atau pahit bergantung pada struktur genetik setiap individu [7].

Kemampuan seseorang untuk mengecap rasa pahit dari PTC disebut dengan Taster dan yang tidak mampu mengecap disebut non Taster. Kemampuan mengecap rasa pahit dipengaruhi oleh gen autosomal dominan T. Gen autosomal dominan akan terekspresi apabila suatu individu memiliki alel dominan [8]. Gen dominan $\mathrm{T}$ akan menutupi alel resesif $\mathrm{t}$ sehingga individu yang memiliki alel Tt mampu mengecap rasa pahit dari PTC. Seseorang yang dinyatakan sebagai Taster terhadap PTC memiliki genotip TT dan Tt sedangkan yang bergenotip tt tidak dapat merasakan rasa pahit dari PTC atau disebut dengan non Taster[9].

Individu non Taster dilahirkan dari pasangan non Taster dengan non Taster atau Taster heterozigot dengan Taster heterozigot, atau non Taster dengan Taster heterozigot. Jumlah penduduk yang dikategorikan sebagai Taster dan non Taster dapat menunjukkan proporsi alel $\mathrm{T}$ dan $\mathrm{t}$. Frekuensi alel $\mathrm{T}$ didapatkan dari individu Taster. Frekuensi alel t didapatkan dari individu Taster heterozigot dan non Taster[10]. Oleh karena perkawinan Upek-Upekan pada suku Osing di desa Kemiren Banyuwangi dapat menurunkan variasi genetik maka perlu dilakukan penelitian tentang studi genetik terhadap kemampuan mengecap PTC pada suku Osing desa Kemiren kabupaten Banyuwangi.

\section{METODE PENELITIAN}

Prosedur penelitian terdiri atas penentuan jumlah sampel, pembuatan larutan PTC, pengambilan data, dan analisis data. Sampel yang digunakan dalam penelitian ini adalah penduduk Suku Osing Desa Kemiren Kabupaten Banyuwangi yang berusia 15-30 tahun karena pada usia tersebut, seseorang mampu menginterpretasikan rasa dengan baik. Penetapan usia sampel dipengaruhi oleh jumlah papila. Semakin bertambahnya usia, jumlah papila akan mengalami penurunan.Sampel yang diamati sebanyak 227 orang dan diambil secara acak. 227 merupakan jumlah ideal yang dapat menggambarkan kondisi populasi Suku Osing yang volume penduduk berusia 15-30 tahun sebanyak 500 dengan pertimbangan toleransi kesalahan sebesar 0,05. Sampel yang diambil merupakan perwakilan dari setiap dusun di desa Kemiren. Pembuatan larutan PTC dengan cara melarutkan 0,133 gram kristal PTC ke dalam $100 \mathrm{ml}$ $\mathrm{ddH}_{2} \mathrm{O}$ steril sebagai larutan no.1 sebagai larutan dengan konsentrasi tertinggi. Larutan no.1 diencerkan sebanyak 50\% untuk digunakan sebagai larutan no. 2 dan seterusnya hingga didapatkan larutan no.14 sebagai larutan dengan konsentrasi terendah [11].

Pengambilan data dilakukan dengan pemberian larutan PTC pada cotton buds ke lidah responden selama 5-10 detik. Responden diminta untuk menginterpretasikan rasa dari larutan PTC. Apabila responden merasakan rasa pahit dari PTC maka responden dikategorikan sebagai Taster. Apabila responden tidak merasakan rasa pahit dari larutan PTC no.14, maka responden dikategorikan sebagai non Taster. Analisis data yang dilakukan adalah prevalensi penduduk yang dikategorikan sebagai Taster dan non Taster, frekuensi alel $\mathrm{T}$ dan $\mathrm{t}$, dan pengujian Hukum Kesetimbangan Genetik Hardy-Weinberg.

Persentase penduduk Taster dan Non Taster dapat diketahui menggunakan persamaan :

$$
\text { Persentase Taster }=\frac{\text { Jumlah Taster }}{\text { Total Individu }} \times 100 \%
$$

Persentase Non Taster $=\frac{\text { Jumlah Non Taster }}{\text { Total Individu }} \times 100 \%$ [8]

Frekuensi alel $\mathrm{T}$ dan $\mathrm{t}$ diketahui menggunakan persamaan :

$$
\begin{aligned}
& (\mathrm{p}+\mathrm{q})^{2}=1 \\
& \mathrm{P}^{2}+2 p q+\mathrm{q}^{2}=1 \\
& \mathrm{q}=\sqrt{\mathrm{q}^{2}} \\
& \mathrm{p}=1-\mathrm{q}
\end{aligned}
$$

Keterangan :

$\mathrm{p}^{2}=$ jumlah penduduk taster (homozigotdominan)

$2 p q=$ jumlah penduduk taster (heterozigot)

$\mathrm{q}^{2}=$ jumlah penduduk non-taster (homozigot resesif)

$\mathrm{q}=$ frekuensi gen resesif autosomal ( $\mathrm{t})$

$\mathrm{p}=$ frekuensi gen dominan autosomal $(\mathrm{T})$

Pengujian Hukum Kesetimbangan Genetik HardyWeinberg menggunakan persamaan:

$$
x^{2}=\sum \frac{(0-e)}{e}
$$

Keterangan :

$\mathrm{X}^{2}=$ nilai uji chi-square

$\mathrm{e}=$ expected (jumlah fenotip yang diharapkan)

$\mathrm{o}=$ observed (jumlah fenotip yang didapat). 


\section{HASIL DAN PEMBAHASAN}

Kemampuan mengecap PTC pada populasi manusia sangat bervariasi dan pewarisannya secara resesif autosom [12]. Proporsi fenotip non Taster $(7,48 \%)$ pada populasi Suku Osing Desa Kemiren masih tergolong rendah dibandingkan dengan populasi Suku Jawa (11\%)[14] dan Suku Tengger $(10,4 \%)[20]$. Penelitian sebelumnya telah dilakukan pada populasi Nigeria dan Syed.Populasi Nigeria memiliki proporsi fenotip non Taster sebesar 2\% \% [12] dan populasi Syed sebesar 33,33\%[13]. P. daan frekuensi non Taster di setiap populasi bc_eda karena setiap populasi memiliki karakteristik tersendiri [6]. Proporsi fenotip Taster dan non Taster yang diperoleh dapat dilihat pada Tabel 1 .

Individu non Taster dianalisa lebih lanjut untuk mengetahui pola pewarisan sifat non Taster dari diagram silsilah keluarga. Diagram silsilah keluarga individu non Taster dapat dilihat pada Gambar 1. Individu non Taster memiliki parental Taster dengan non Taster, Taster heterozigot dengan Taster heterozigot, dan non Taster dengan non Taster. Parental yang tidak teridentifikasi diduga memiliki genotip Tt karena memiliki keturunan yang bersifat non Taster.

Tabel 1. Proporsi fenotip Taster dan non Taster pada populasi suku Osing Desa Kemiren Kabupaten Banyuwangi

\begin{tabular}{ccccccc}
\hline \multirow{2}{*}{ Fenotip } & \multicolumn{4}{c}{ Jenis Kelamin } & \multirow{2}{*}{ Jumlah Sampel } \\
\cline { 2 - 6 } & \multicolumn{2}{c}{ Laki-Laki } & \multicolumn{2}{c}{ Perempuan } & & \\
\cline { 2 - 6 } & $\mathrm{N}$ & $\%$ & $\mathrm{~N}$ & $\%$ & $\mathrm{~N}$ & $\%$ \\
\hline Taster & 105 & $46,26 \%$ & 105 & $46,26 \%$ & 210 & $92,52 \%$ \\
Non Taster & 12 & $5,28 \%$ & 5 & $2,20 \%$ & 17 & $7,48 \%$ \\
Total & 117 & $51,54 \%$ & 110 & $48,46 \%$ & 227 & $100 \%$ \\
\hline
\end{tabular}

Proporsi Taster pada populasi lebih besar daripada proporsi Non Taster. hal ini disebabkan karena Taster memiliki 2 kemungkinan genotip yaitu TT dan Tt sedangkan non Taster hanya memiliki 1 genotip yaitu tt. Perbandingan proporsi Taster dan non Taster adalah 2:1 sehingga dalam suatu populasi individu Taster lebih mendominasi [12].

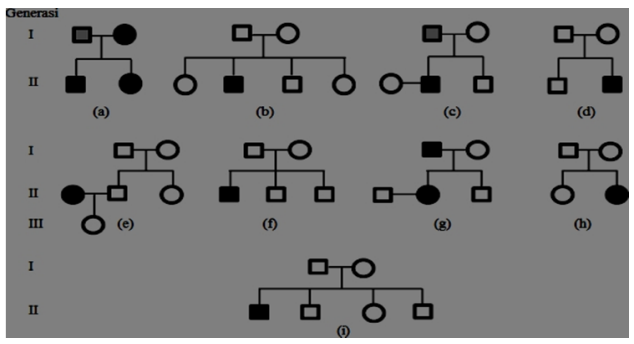

Gambar 1. Diagram silsilah individu non Taster Keterangan :

$$
\begin{aligned}
& =\text { Tidak teridentifikasi } \\
& =\text { Laki-laki Taster } \\
& =\text { Laki-laki non Taster } \\
& =\text { Perempuan Taster } \\
& =\text { Perempuan non Taster }
\end{aligned}
$$

Frekuensi alel $\mathrm{T}$ dan t pada populasi suku Osing desa Kemiren kabupaten Banyuwangi dapat dilihat pada Tabel 2. Frekuensi alel pada populasi Suku Osing berbeda dengan populasi yang lain yang telah diamati oleh peneliti sebelumnya. Perbedaan frekuensi alel spesifik untuk setiap populasi sehingga dapat digunakan sebagai identitas suatu populasi [12]. Frekuensi alel $\mathrm{T}$ lebih tinggi daripada alel t. Alel T bersifat dominan dan kemungkinan alel $\mathrm{T}$ diwariskan lebih besar daripada alel t. Sehingga alel T lebih banyak ditemukan daripada alel t [9]. Frekuensialel t pada populasi suku Osing $(0,27)$ tergolong rendah apabila dibandingkan dengan frekuensi alel pada suku Jawa yang mencapai 0,33 [14]. Berdasarkan data yang diperoleh, viabilitas alel t pada suku Osing lebih rendah dibandingkan suku Jawa. Perbedaan frekuensi alel pada populasi yang memiliki sistem perkawinan yang sama disebabkan oleh perbedaan frekuensi alel parental terdahulu. Frekuensi alel yang didapatkan saat ini merupakan gambaran penyebaran gen pada generasi sebelumnya [15].

Tabel 2. Frekuensi alel $\mathrm{T}$ dan $\mathrm{t}$

\begin{tabular}{ccccccc}
\hline \multirow{3}{*}{ Alel } & \multicolumn{4}{c}{ Jenis Kelamin } & \multirow{2}{*}{ Jumlah Sampel } \\
\cline { 2 - 7 } & $\mathrm{N}$ & Frekuensi & $\mathrm{N}$ & Frekuensi & $\mathrm{N}$ & Frekuensi \\
\hline $\mathrm{T}$ & 105 & 0,68 & 105 & 0,75 & 210 & 0,73 \\
$\mathrm{~T}$ & 12 & 0,32 & 5 & 0,21 & 17 & 0,27 \\
Jumlah & 117 & 1 & 110 & 1 & 227 & 1 \\
\hline Setiap & \multicolumn{3}{c}{ individu } & memiliki & genotip yang \\
menggambarkan suatu & sifat. Sifat & kemampuan
\end{tabular}


mengecap rasa pahit dari PTC terdiri dari tiga genotip, yaitu genotip TT, Tt, dan tt. TT merupakan homozigot dominan dan menghasilkan individu Taster. Tt merupakan heterozigot dan menghasilkan individu Taster namun bersifat carrier. tt merupakan homozigot resesif yang menghasilkan individu non Taster. Individu dengan genotip heterozigot dapat mengecap rasa pahit dari PTC karena memiliki alel dominan $\mathrm{T}$ yang menutupi sifat resesif dari $\mathrm{t}[16]$. Frekuensi genotip pada populasi Suku Osing didominasi oleh genotip TT. Hal ini disebabkan karena frekuensi alel didominasi oleh alel $\mathrm{T}$ yang memiliki viabilitas lebih tinggi daripada alel t. Genotip TT memiliki alel dominan-dominan, Tt dominan-resesif, dan tt resesif-resesif sehingga pada populasi pada umumnya didominasi oleh genotip TT [13]. Frekuensi genotip dapat dilihat pada Tabel 3 .

Tabel 3. Genotip pengecap PTC

\begin{tabular}{ccccccc}
\cline { 2 - 5 } Genotip & \multicolumn{4}{c}{ Jenis Kelamin } & \multicolumn{2}{c}{ Total } \\
\cline { 2 - 5 } & \multicolumn{2}{c}{ Laki-laki } & \multicolumn{2}{c}{ Perempuan } & & \\
\cline { 2 - 6 } & $\mathrm{N}$ & Frekuensi & $\mathrm{N}$ & Frekuensi & $\mathrm{N}$ & Frekuensi \\
\hline TT & 54 & 0,46 & 69 & 0,62 & 113 & 0,54 \\
Tt & 51 & 0,44 & 37 & 0,34 & 88 & 0,39 \\
tt & 12 & 0,10 & 4 & 0,04 & 16 & 0,07 \\
Total & 117 & 1 & 110 & 1 & 227 & 1 \\
\hline
\end{tabular}

Heterozigositas merupakan nilai yang menggambarkan keanekaragaman genetik. Nilai heterozigositas yang diperoleh dari hasil penelitian ini tergolong tinggi $(0,39)$. Nilai heterozigositas berkisar antara 0-1. Standar heterozigositas suatu populasi terdiri atas rendah $(<20)$, sedang (20-30), dan tinggi (>30) [17]. Homozigositas merupakan nilai yang menggambarkan keseragaman genetik yang dipengaruhi oleh silang dalam atau inbreeding. Inbreeding dapat meningkatkan homozigositas dan mengurangi heterozigositas[18], [19]. Nilai heterozigositas dan homozigositas populasi Suku Osing Desa Kemiren dapat dilihat pada Tabel 4.

Tabel 4. Heterozigositas dan homozigositas

\begin{tabular}{ccccccc}
\hline $\begin{array}{c}\text { Keseragaman } \\
\text { Alel }\end{array}$ & \multicolumn{4}{c}{ Jenis Kelamin } & \multicolumn{2}{c}{ Total } \\
& Laki-Laki & Perempuan & & \\
& $\mathrm{N}$ & $\begin{array}{c}\text { Freku } \\
\text { ensi }\end{array}$ & $\mathrm{N}$ & $\begin{array}{c}\text { Freku } \\
\text { ensi }\end{array}$ & $\mathrm{N}$ & $\begin{array}{c}\text { Freku } \\
\text { ensi }\end{array}$ \\
\hline Heterozigositas & 51 & 0,44 & 37 & 0,34 & 89 & 0,39 \\
Homozigositas & 66 & 0,56 & 73 & 0,66 & 138 & 0,61 \\
Jumlah & 117 & 1 & 110 & 1 & 227 & 1 \\
\hline
\end{tabular}

Hasil pengujian kesetimbangan genetik dengan tes Chi-Square menunjukkan nilai tes Chi-square adalah 0,0044 pada derajat bebas $=1$, dengan nilai probabilitas terletak pada nilai kemungkinan 0.9-0.99 atau lebih besar dari 0.05 (Tabel 5). Hal ini menunjukkan tidak ada penyimpangan yang signifikan pada proporsi genotip Taster dan non Taster hasil observasi.

Tabel 5. Uji Chi Square

\begin{tabular}{cccccc}
\hline Observed (o) & Expected(e) & $\boldsymbol{d}$ & $(\boldsymbol{d}-\mathbf{0}$ & $\frac{(\boldsymbol{d}-\mathbf{0 . 5})^{\mathbf{2}}}{\boldsymbol{e}}$ \\
\hline Taster & 210 & 210,45 & $-0,45$ & 0,9025 & 0,0043 \\
Non & 17 & 16,55 & 0,45 & 0,0025 & 0,0001 \\
Taster & & & & & \\
Total & 227 & 227 & 0,9 & 0,9050 & X2: 0,0044 \\
\hline
\end{tabular}

Dengan demikian maka proporsi genotip Taster dan non Taster pada populasi suku Osing desa Kemiren kabupaten Banyuwangi dalam kategori seimbang yaitu memenuhi hukum kesetimbangan genetik Hardy-Weinberg. Kesetimbangan alel T dan t pada populasi Suku Osing diduga disebabkan oleh ukuran populasi yang besar, masih terdapat aliran gen, tidak terjadi mutasi dan tidak terjadi seleksi.

\section{KESIMPULAN}

Persentase Taster penduduk suku Osing desa Kemiren kabupaten Banyuwangi adalah 92,52\% dan non Taster adalah 7,48\%. Frekuensi alel dominan Taster ( $\mathrm{T}$ ) adalah 0,73 dan alel resesif non Taster ( $\mathrm{t}$ ) adalah 0,27. Frekuensi genotip Taster homosigot dominan (T'T) adalah 0,54. Frekuensi genotip Taster heterosigot $(\mathrm{Tt})$ adalah 0,39, dan frekuensi genotip homosigot resesif non Taster (tt) adalah 0.07. Hasil uji kesetimbangan Hardy-Weinberg menunjukkan proporsi genotip Taster dan non Taster tidak memiliki penyimpangan yang sifnifikan sehingga masih memenuhi hukum kesetimbangan genetik HardyWeinberg.

\section{UCAPAN TERIMA KASIH}

Penulis mengucapkan terimakasih kepada Universitas Jember yang telah memberikan sarana dan prasarana demi berlangsungnya penelitian ini. Bapak/Ibu pembimbing dan penguji yang telah memberikan saran dalam pelaksanaan penelitian. 
Penduduk desa Kemiren Kabupaten Banyuwangi yang telah bersedia menjadi probandus penelitian.

\section{DAFTAR PUSTAKA}

[1] R. Sufia, Sumarmi, and A. Amirudin, "Kearifan Lokal Dalam Melestarikan Lingkungan Hidup (Studi Kasus Masyarakat Adat Desa Kemiren Kecamatan Glagah Kabu," J. Pendidik. Teor. Penelitian, dan Pengemb., vol. 1, no. 4, pp. 726-731, 2016.

[2] S. Rofikoh, "Strategi Masyarakat Suku Osing dalam Melestarikan Adat-Istiadat Pernikahan di Tengah Modernisasi (Studi Kasus di Desa Kemiren Kecamatan Glagah Kabupaten Banyuwangi)," Universitas Islam Negeri Sunan Ampel Surabaya, Surabaya, 2018.

[3] F. Azhari, Z. Muttaqien, and S. Kurdi, "Motivasi Perkawinan Endogami pada Komunitas Alawiyyin di Martapura Kabupaten Banjar [The Motivation of Endogamic Marriage on Alawiyyin Community in Martapura, Banjar]," Mu'adalab J. Stud. Gend. dan Anak, vol. 1, no. 2, pp. 85-102, 2013.

[4] R. H. . S. R. Matondang, "Langkah-langkah Strategis Dalam Mencapai Swasembada Daging Sapi/Kerbau 2014," J. Litbang Peternak., vol. 32, no. 2, pp. 131-139, 2013.

[5] F. . Allendorf, Conservation and The Genetics of Population. Victoria: Blackwell Publishing, 2009.

[6] O. V. Filiptsova, I. A. Timoshyna, Y. N. Kobets, M. N. Kobets, I. S. Burlaka, and I. A. Hurko, "The Population Structure of Ukraine in Relation To The Phenylthiocarbamide Sensitivity," Egypt. J. Med. Hum. Genet., vol. 16, no. 2, pp. 135-139, 2015.

[7] J. Tan, "3D Structure Prediction of TAS2R38 Bitter Receptors Bound to Agonists Phenylthiocarbamide (PTC) and 6-n-Propylthiouracil (PROP)," J. Chem. Inf. Model., vol. 52, pp. 1875-1885, 2012.

[8] S. . Elord, Genetika Edisi Keempat. Jakarta: Erlangga, 2006.

[9] A. Jaiswal, "A Study of Taste Sensitivity of Phenylthiocarbamide and Colour blindness among the Jats of District Rohtak ( Haryana ) A Study of Taste Sensitivity of Phenylthiocarbamide and Colour Blindness Among The Jats of District Rohtak ( Haryana )," no. January 2011, 2014.

[10] Suryo, Genetika untuk Strata 1. Yogyakarta: UGM Press, 2013.

[11] M. Fareed, A. Shah, R. Hussain, and M. Afzal, "Genetic Study of Phenylthiocarbamide (PTC) Taste Perception Among Ssix Human Populations of Jammu and Kashmir (India)," Egypt. J. Med. Hum. Genet., vol. 13, no. 2, pp. 161-166, 2012.
[12] C. G. Alimba, K. O. Adekoya, and B. O. Oboh, "Prevalence and Gene Frequencies of Phenylthiocarbamide (PTC) Taste Sensitivity, ABO and Rhesus Factor (Rh) Blood Groups, and Haemoglobin Variants Among a Nigerian Population," Egypt. J. Med. Hum. Genet., vol. 11, no. 2, pp. 153-158, 2010.

[13] G. Ara, Y. H. Siddique, T. Beg, and M. Afzal, "Gene Diversity Among Some Muslim Populations of Western Uttar Pradesh, India," Anthropologist, vol. 10, no. 1, pp. 5-9, 2008.

[14] D. Ratmawati, "Kemampuan Mengecap Phenylthiocarbamida (PTC) pada Warga Desa Jatigunung Kecamatan Tulakan Kabupaten Pacitan," Universitas Jember, 2003.

[15] Darmawati, E. Suryawati, and E. Suhendri, "Frekuensi dan Penyebaran Alel Golongan Darah A B O Siswa SMUN 1 Suku Bangsa Melayu di Kecamatan Rupat Kabupaten Bengkalis Riau," J. Biog., vol. I, no. 2, pp. 66-69, 2005.

[16] R. Hussain, A. Shah, and M. Afzal, "Distribution of Sensory Taste Thresholds for Phenylthiocarbamide (PTC) Taste Ability in North Indian Muslim Populations," Egypt.J. Med. Hum. Genet., vol. 14, no. 4, pp. 367-373, 2013.

[17] M. Na'iem, Genetic Variation of Shorea leprosula Miq. In Three Population in Indonesia: Implication for Ex Situ Conservation," Bul. Kehutan., vol. 49, pp. 12-25, 2001.

[18] R. Faizah, S. Wening, H. Y. Rahmadi, and A. R. Purba, "The Suspect Symptoms of Inbreeding Depression and The Homozygosity Level of Fourth Generation of SP450T and Fifth Generation of Dura Deli Oil Palm Selfing Population," J. Penelit. Kelapa Sawit, vol. 24, no. 2, pp. 55-66, 2016.

[19] D. Mulliadi and J. Arifin, "Pendugaan Keseimbangan Populasi dan Heterozigositas Menggunakan Pola Protein Albumin Darah pada Populasi Domba Ekor Tipis (Javanese Thin Tailed) di Daerah Indramayu (Prediction Equilibrium of Population Used Blood Albumin Pattern of Thin Tailed Sheep," J. Ilmu Ternak, vol. 10, no. 2, pp. 65-72, 2010.

[20] SD. Maharani, "Kemampuan Mengecap Phenylthiocarbamida (PTC) pada Suku Tengger di Desa Ranupani Kecamatan Senduro Kabupaten Lumajang Propinsi Jawa Timur," Universitas Jember, 2005. 